\title{
In vitro study of the PLA2 inhibition and antioxidant activities of Aloe vera leaf skin extracts
}

\author{
Maher Kammoun ${ }^{1}$, Sonia Miladi ${ }^{2}$, Yassine Ben Ali ${ }^{1}$, Mohamed Damak ${ }^{2}$, Youssef Gargouri ${ }^{1}$, Sofiane Bezzine ${ }^{1 *}$
}

\begin{abstract}
Background: In the present work we determined the total phenolic content of Aloe vera leaf skin (AVLS) extracts by using various solvents (hexane, chloroform-ethanol (1/1), ethyl acetate, butanol and water). We have also evaluated the antioxidant and the anti-PLA2 properties of these extracts by measuring their inhibition potency on the human pro-inflammatory phospholipase A2 (group IIA).

Results: The water extract exhibits the highest inhibitory effect with an $\mathrm{IC}_{50}=0.22 \mathrm{mg} / \mathrm{ml}$ and interestingly no effect was observed on the digestive phospholipase A2 (group IB) even at a concentration of $5 \mathrm{mg} / \mathrm{ml}$. Antioxidant activities were also analyzed and the most active extracts were observed when using chloroform ethanol (1/1) and ethyl acetate $\left(I C_{50}=0.274\right.$ and $0.326 \mathrm{mg} / \mathrm{ml}$, respectively). Analysis of the total phenolic content reveals that the water extract, with the best anti-PLA2 effect, was poor in phenolic molecules ( $2 \mathrm{mg} \mathrm{GAE} / \mathrm{g}$ ). This latter value has to be compared with the chloroform-ethanol and the ethyl acetate extracts (40 and $23.8 \mathrm{mg} \mathrm{GAE} / \mathrm{g}$, respectively), mostly responsible for the antioxidant activity.
\end{abstract}

Conclusion: A significant correlation was established between the total phenolic content and the antioxidant capacity but not with the anti PLA2 activity. Results from phytochemical screening suggest that the anti PLA2 molecules were probably catechin tannins compounds.

\section{Background}

Aloe vera L. (syn.: Aloe barbadensis Miller) is a perennial succulent plant belonging to the Aloeaceae family (sub-family of the Asphodelaceae) [1]. Among over 400 Aloe species, Aloe vera is the most accepted specie for various medical, cosmetic and neutraceutical purposes [2-4]. The plant is made of turgid green leaves joined at the stem in a rosette pattern. Each leaf consists of two parts: an outer green rind (skin) and an inner clear pulp (gel). The plant was described to contain a large amount of phenolic compounds [2,5-10] with a high content of 1,8-dihydroxyanthraquinone derivatives (aloe emodin) and glycosides (aloins), which were used as cathartic [11-13]. Various studies have revealed that Aloe vera leaf skin $(A V L S)$ possesses many pharmaceutical properties, including purgative [14], antibacterial [15,16], anticancer [17-19], antifungal [20] and antioxidant [21-25].

\footnotetext{
* Correspondence: sofiane_bezzine@yahoo.com

'Laboratoire de Biochimie et de Génie Enzymatique des Lipases, Ecole

Nationale d'Ingénieurs de Sfax, University of Sfax, Tunisia

Full list of author information is available at the end of the article
}

The secreted phospholipases A2 (sPLA2) are low molecular mass enzymes (14-19 kDa) with a rigid tertiary structure due to five to eight disulfide bonds that probably confer resistance against proteolysis and thermal denaturation $[26,27]$. These enzymes hydrolyze the $\mathrm{Sn}$-2 ester bond of glycerophospholipids to liberate free fatty acid and lysophospholipid. So far, eleven sPLA2 have been described in mammals and they belong to groups IB, IIA, IIC, IID, IIE, IIF, III, V, X, XIIA and XIIB. The first non pancreatic mammalian identified sPLA2 was the group IIA enzyme which plays important roles in the initiation and amplification of the inflammatory reaction. Arachidonic acid is metabolized by either the cyclo-oxygenase or the lipo-oxygenase enzymatic pathway to produce diverse families of eicosanoids including prostaglandins and leukotrienes are involved in inflammation related processes $[28,29]$.

Based on the central role of lipid mediators in the inflammatory processes, the potential value of controlling phospholipid metabolism through PLA2 inhibition has always been acknowledged [30]. Numerous compounds have been proposed as inhibitors of various 
SPLA2. However, clinical studies have never reached a therapeutical stage. The aim of this study was firstly to investigate the phytochemical composition of AVLS and secondly to evaluate some biochemical activities of the ethanolic extracts of AVLS such as their antioxidant capacity and their inhibitory effects on the pro-inflammatory phospholipase A2 group IIA. As a control experiment, we used the digestive pancreatic phospholipase A2 group IB.

\section{Results}

\section{Extraction yields and phytochemical screening of Aloe} vera leaf skin

Aloe vera leaf skin was harvested in august and the extraction yields were summarized in table 1 . These results show the various phytochemical families present in AVLS fractions. Tests for steroids, terpenoids and carotenoids were positive in both hexane and ethyl acetate fractions. Anthraquinones were mostly detected in the ethyl acetate, chloroform-ethanol and butanol fractions while alkaloids and flavonoids were absent in all fractions. It is worth noticing that catechin tannins were only detected in the aqueous extract.

\section{Total phenolic contents}

Results of the total phenolic contents from the various extracts, expressed as milligram of GAEs per gram of extract, were presented in table 2. Among the five extraction systems used, the chloroform-ethanol extract showed the highest amount of phenolic compounds (40.5 $\mathrm{mg} \mathrm{GAE} / \mathrm{g}$ ) and the poorest one was the water extract which contained only $2.07 \mathrm{mg} \mathrm{GAE} / \mathrm{g}$.

\section{Antioxidant activity \\ DPPH radical scavenging activity}

The antiradical activities of extracts were determined using the DPPH free radical assay. After the measurement

Table 1 Phytochemical screening and yields of AVLS extracts

\begin{tabular}{lccccc}
\hline Extracts & Hexane & $\begin{array}{c}\text { Ethyl } \\
\text { acetate }\end{array}$ & $\begin{array}{c}\text { Chloroform- } \\
\text { ethanol }\end{array}$ & Butanol & Water \\
\hline Yields (\%) & 5.10 & 11.20 & 6.09 & 8.57 & 66.67 \\
\hline Steroids & ++ & + & - & - & - \\
Terpenoids & ++ & ++ & - & - & - \\
Carotenoids & + & + & - & - & - \\
Anthraquinones & - & ++ & +++ & + & - \\
Flavonoids & - & - & - & - & - \\
Alkaloids & - & - & - & - & - \\
Catechin & - & - & - & - & +++ \\
tannins & & & & & \\
\hline
\end{tabular}

The yields were determined as relative to the initial amount of dry ethanolic extract $(79.8 \mathrm{~g})$.

-: Absent, +: Present, ++: Rich, +++: Very rich.
Table 2 Total phenol content and $I_{50}$ on DPPH of AVLS extracts

\begin{tabular}{lcc}
\hline Extracts & $\begin{array}{c}\text { TPC (mg GAE/g of } \\
\text { extract) }\end{array}$ & $\begin{array}{c}\mathrm{IC}_{50} \text { on DPPH radical } \\
(\mathbf{m g} / \mathbf{m l})\end{array}$ \\
\hline Hexane & $9.600 \pm 0.014$ & 0.366 \\
Ethyl acetate & $23.800 \pm 0.058$ & 0.326 \\
Chloroform-ethanol & $40.500 \pm 0.041$ & 0.274 \\
$(\mathbf{1} / \mathbf{1})$ & $16.900 \pm 0.039$ & 0.635 \\
Butanol & $2.072 \pm 0.002$ & $>1$ \\
Water & - & $6910^{-3}$ \\
\hline BHT & - & $7.510^{-3}$ \\
$\boldsymbol{\alpha}$-tocopherol & - &
\end{tabular}

$\mathrm{IC}_{50}$ values on DPPH were calculated from the plot of the scavenging effect against the extract concentration. Effects of BHT and $\alpha$-tocopherol, used as standard, were measured in the same conditions. All experiments were performed in triplicate \pm standard deviation.

of absorbance at $517 \mathrm{~nm}$, the radical scavenging activities of the various extracts were expressed as the mean of the $\mathrm{IC}_{50}$ values $(\mathrm{mg} / \mathrm{ml}) . \mathrm{IC}_{50}$ values of the five $A V L S$ extracts, $\alpha$-tocopherol and BHT are reported in table 2 .

Our results show that the chloroform-ethanol $(1 / 1)$ extract of leaf skin exhibits the highest capacity to reduce $\mathrm{DPPH}\left(\mathrm{IC}_{50}=0.274 \mathrm{mg} / \mathrm{ml}\right)$, followed by the ethyl acetate extract $\left(\mathrm{IC}_{50}=0.326 \mathrm{mg} / \mathrm{ml}\right)$ and the hexane extract $\left(\mathrm{IC}_{50}=0.366 \mathrm{mg} / \mathrm{ml}\right)$. The lowest antiradical capacity was found in the water extract. For the sake of comparison, we measured the $\mathrm{IC}_{50}$ value of $\mathrm{BHT}$ and $\alpha$-tocopherol which were 69 and $7.5 \mu \mathrm{g} / \mathrm{ml}$ respectively.

Reducing power assay

Results presented in Figure 1 show the reducing power of the $A V L S$ fractions and BHT, used as reference. As expected, the reducing power of all samples tested is proportional to their concentrations. Below $0.2 \mathrm{mg} / \mathrm{ml}$ no significant difference was seen among all extracts. However differences were more pronounced with extracts at concentrations higher than $0.5 \mathrm{mg} / \mathrm{ml}$. According to the results presented in Figure 1, ethyl acetate, chloroform-ethanol and butanol extracts were found to be better radical reducer (with electron donating capacities) as compared to water and hexane extracts. However, these extracts are less effective than BHT, a widely used commercial antioxidant which exhibits a high reducing capacity even when used at very low concentrations $(0.05 \mathrm{mg} / \mathrm{ml})$.

\section{Evaluation of PLA2 inhibitory effect}

To evaluate the potential anti-inflammatory activity of AVLS, we tested the inhibitory effects of various extracts using two secreted phospholipases: hG-IIA involved in the inflammatory process and the pG-IB which hydrolyzes dietary phospholipids. Our main objective was to find an extract which was able to inhibit selectively the pro-inflammatory phospholipase A2 group IIA with no 


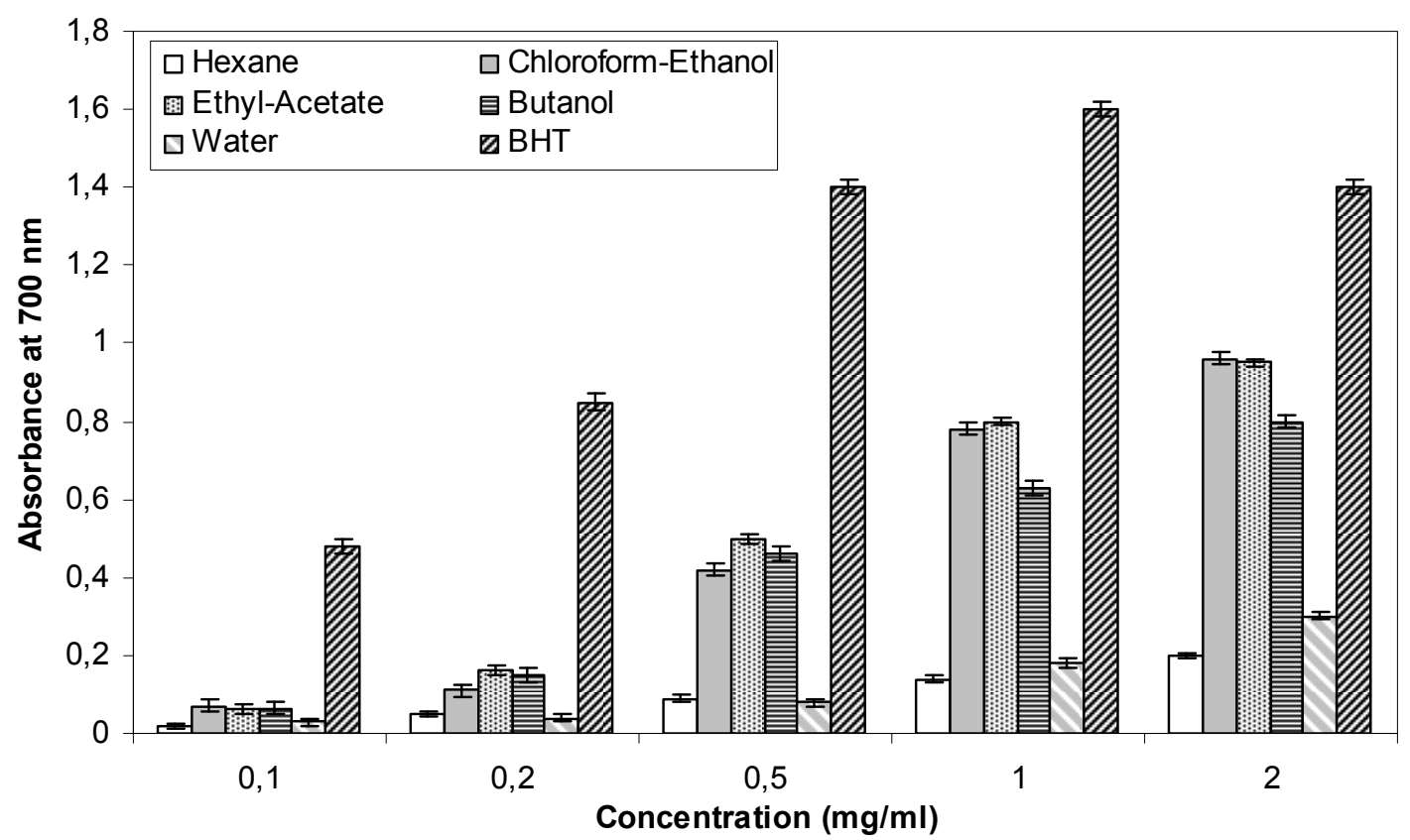

Figure 1 Reducing power of AVLS measured with hexane, chloroform-ethanol, ethyl acetate, butanol and water extracts as compared to BHT. Experiments were performed in triplicate \pm standard deviation.

or minimal inhibitory effect on the digestive phospholipase A2 group IB.

Out of the 5 extracts screened, three of them (ethyl acetate, chloroform-ethanol (1/1) and water) showed significant results (Figure 2). It is worth noticing that the water extract shows the most promising results in inhibiting the catalytic activity of the hG-IIA with an $\mathrm{IC}_{50}$ of $0.22 \mathrm{mg} / \mathrm{ml}$. In sharp contrast, using the same extract even at concentrations higher than $5 \mathrm{mg} / \mathrm{ml}$, no inhibition of the phospholipase A2 activity of pG-IB was noticed. These results indicate a selective inhibition of the water extract against these two sPLA2.

\section{Correlation significance study}

It was worth studying the potential correlations between the phenolic content of AVLS extracts with their antioxidant capacity and their inhibition of phospholipase A2 activity, since it was previously reported that phenolic compounds contribute directly to the antioxidant activity [31] and to the anti-inflammatory effects [32].

A correlation analysis was performed between the total phenolic content, the antioxidant activity and the phospholipase A2 inhibition described in the present study. Results reported in table 3 show a linear regression and a significant relationship between the total phenolic content and free radical scavenging or reduction power $(\mathrm{r}=0.9, \mathrm{P}<0.05)$. As expected, our results indicate that in the presence of high concentrations of the phenolic compounds, the antioxidant activity increases significantly. Furthermore, a positive correlation was also noticed between the total phenolic content and their inhibitory effect on pG-IB $(\mathrm{r}=0.78, \mathrm{P}<0.1)$ but no significant correlation was obtained between the phenolic content and the hG-IIA inhibition.

\section{Discussion}

The heterogeneity of the phytochemical composition of AVLS extracts is very promising for future medical applications. In fact, the chloroform-ethanol extract, which is rich in phenolic compounds (40.5 mg GAE/g), was the best antioxidant tested. In contrast, the water extract which is the poorest in phenolic compounds (2.07 mg GAE/g) did not show any antioxidant activity. This finding suggests that phenolic compounds from AVLS are responsible for the antioxidant effect. These results in agreement with those obtained by Kahkonen et al. (1999) [33], Shahidi and Marian (2003) [34] who reported that the differences in antioxidant activities of plant extracts could be due to the variable contents of their phenolic compounds. In the search for natural anti-inflammatory compounds, several studies were performed using Aloe vera due to its well known potent anti-inflammatory effects. Several authors have demonstrated the anti-inflammatory effect of this plant. Habeeb et al (2007) [35] have shown that the inner leaf gel from Aloe vera, when using an extract at a 


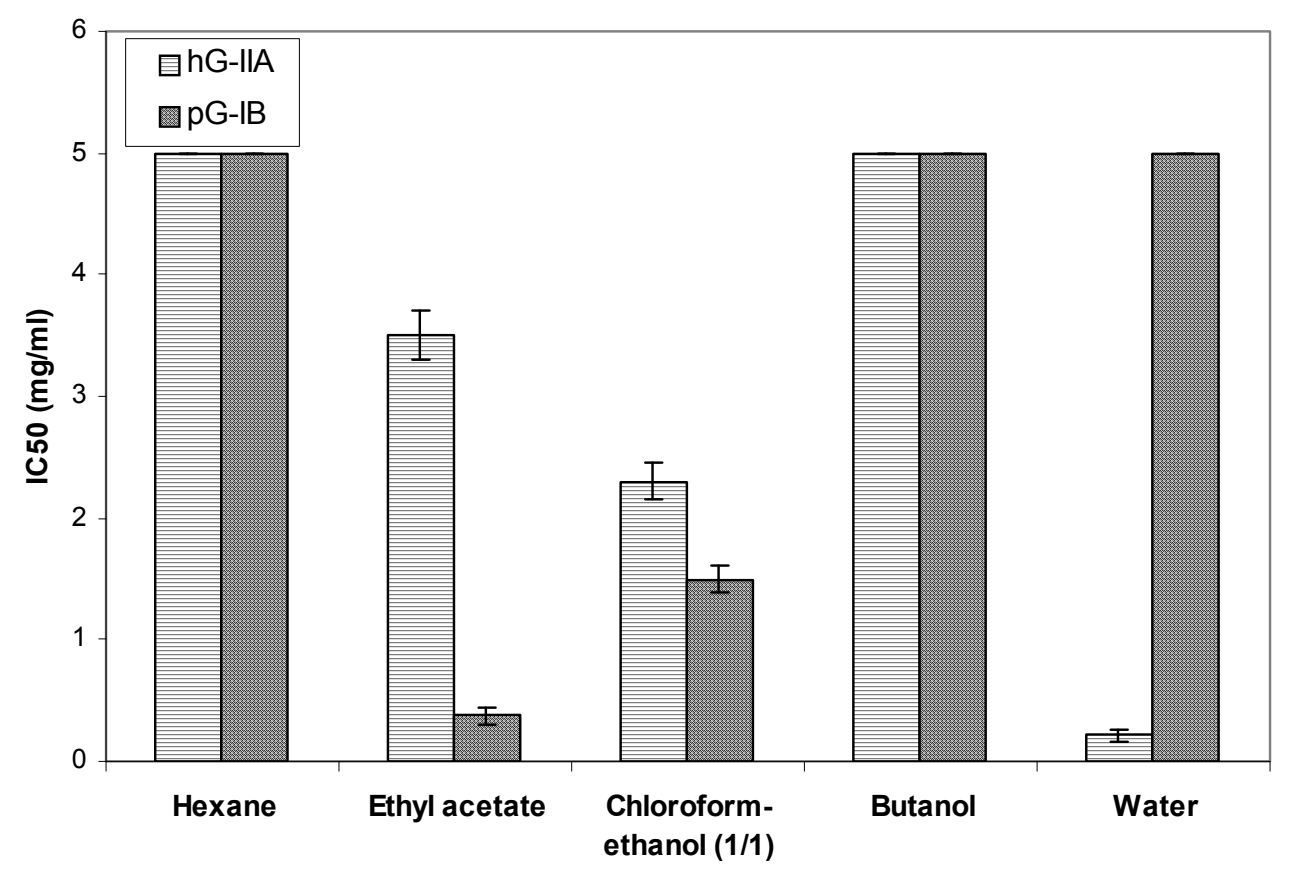

Figure $2 \mathrm{IC}_{50}$ of AVLS extracts measured during the inhibition of hG-IIA and pG-IB. Experiments were performed in triplicate \pm standard deviation.

concentration of around $45 \mathrm{mg} / \mathrm{ml}$, can suppress the cytokine induced inflammation after a whole bacterial stimulation of the human immune cells.

We also report in this study that the water extract of AVLS possesses the best inhibitory effect on the proinflammatory PLA2 group IIA with an $\mathrm{IC}_{50}=0.22 \mathrm{mg} /$ $\mathrm{ml}$. The phytochemical analysis showed that this water extract was very rich in catechin tannins suggesting that, apart from its low concentration in polyphenol contents, the molecules responsible for the anti-PLA2 effects belong probably to different chemical families. Probably the catechin tannins, rich in the water extracts and responsible for the anti-PLA2 activities, are different from the molecules bearing the antioxidant effect. It was previously reported that LY311727 inhibit hG-IIA and pG-IB with an IC50 of 0.47 and 8 $\mu \mathrm{M}$, respectively [36]. In the same case, Me-Indoxam was found to be the most potent inhibitor of sPLA2 and was extensively studied. It is able to inhibit hGIIA with an IC50 of $0.006 \mu \mathrm{M}$ and its IC50 on hG-IB is about $6 \mu \mathrm{M}$ [37].

Several studies evaluated the relationships between the antioxidant activity of plant extracts and their phenolic content. Velioglu et al. (1998) [38] reported a significant relationship between the total phenolic content and its antioxidant activity in selected fruits, vegetables and grain products.

In agreement with these latter results, we report here a significant correlation between the total phenolic compounds and their antioxidant effects $(\mathrm{r}=0.9, \mathrm{P}<0.05)$ as well as during pG-IB inhibition $(\mathrm{r}=0.78, \mathrm{P}<0.1)$. In contrast, no correlation was observed between the phenolic content and the $\mathrm{IC}_{50}$ measured during hG-IIA inhibition. These results suggest that different

Table 3 Correlation significance between the total phenolic content, antioxidant capacity and phospholipase A2 inhibition

\begin{tabular}{|c|c|c|c|c|}
\hline Parameter & Reducing power & $\mathrm{IC}_{50}$ value of scavenging activity & $I C_{50}$ value of hG-IIA inhibition & $\mathrm{IC}_{50}$ value of $\mathrm{pG}$-IB inhibition \\
\hline Number of XY Pairs & 5 & 5 & 5 & 5 \\
\hline Spearman $r$ & 0,9 & $-0,9$ & 0,0513 & $-0,7826$ \\
\hline$P$ value (one-tailed) & 0,0417 & 0,0417 & 0,475 & 0,0667 \\
\hline$P$ value summary & $*$ & * & ns & * \\
\hline $\begin{array}{l}\text { Exact or approximate } P \\
\text { value? }\end{array}$ & Exact & Exact & Exact & Exact \\
\hline $\begin{array}{l}\text { Is the correlation } \\
\text { significant? (alpha }=0.1)\end{array}$ & Yes & Yes & No & Yes \\
\hline
\end{tabular}


compounds are responsible for the inhibition of these two groups of sPLA2. In addition, the catechin tannins, present in the water extract, could be responsible for the inhibition of the hG-IIA activity and not that of pGIB. Several authors have suggested that compounds responsible for the anti-inflammatory effect could not be phenolic molecules. Yagi et al (2003) [39] reported that neutral polysaccharides, aloemannan and acemannan isolated from Aloe vera, exhibited antitumor, antiinflammatory and immunosuppressive activities. Similar results were obtained by Parc et al., (2009) [40] who demonstrated that Aloe-emodin, an anthraquinone compound, extracted from Aloe vera has an anti-inflammatory activity by blocking inducible nitric oxide synthase and cyclooxygenase-2 mRNA expression. Moreover, Esua et al (2005) [41] have isolated two maloyl glucans with significant effect against the gene expression of very important pro-inflammatory cytokines as well as counteracting the effect of the tumor necrosis factor- $\alpha$.

\section{Materials and methods}

\section{Enzymes and reagents}

Human group IIA phospholipase A2 (hG-IIA) and Me-Indoxam were generous gifts from Dr. Gerard Lambeau (IPMC, France). Porcine group IB phospholipase A2 (pG-IB), Egg yolk phosphatidylcholine or lecithin, red phenol and sodium taurodeoxycholate (NaTDC), 2,2Diphenyl-1-picrylhydrasyl (DPPH), potassium phosphate, BHT (butylated hydroxytoluene), $\alpha$-tocopherol and gallic acid were purchased from Sigma Chemical Co. (St.Loui, $\mathrm{MO})$. Potassium ferricyanide, ferric chloride and FolinCiocalteu phenol reagent were purchased from Merck. Visible spectra measurements were performed using Anadéo visible spectrophotometer (Anadéo-Bibby).

\section{Extraction and phytochemical screening}

Mature fresh leaves of Aloe vera (Aloaceae) with an approximate length of 0.5 to $0.7 \mathrm{~m}$ were collected from the region of Kairouan, (Tunisia) and harvested in August 2008. The fresh Aloe vera leaf skin $(3 \mathrm{~kg}$ ) was washed with distilled water and was extracted with 5 liters of ethanol (95\%) by maceration for 48 hours at room temperature. After a filtration step, the ethanolic extract was concentrated under reduced pressure and lyophilized to yield the ethanolic extract $(79.80 \mathrm{~g})$. This extract was suspended in water $(200 \mathrm{ml})$ and partitioned successively with hexane (1 liter), ethyl acetate (4 liters), chloroform-ethanol (1/1, v/v) (1.5 liters) and butanol (1.5 liters). The remaining solution is designated "water extract".

Phytochemical screening was carried out to identify the chemical compounds present in the AVLS extract, in order to determine the chemical nature of the potential active principles responsible for the observed biochemical effects $[42,43]$.

\section{Inhibition of SPLA2 activity}

The test of inhibitory activity of PLA2 was performed as described by De Aranjo and Radvany (1987) [44]. Briefly, the substrate consisted of $3.5 \mathrm{mM}$ lecithin in a mixture of $3 \mathrm{mM} \mathrm{NaTDC}, 100 \mathrm{mM} \mathrm{NaCl}, 10 \mathrm{mM} \mathrm{CaCl} 2$ and 0.055 $\mathrm{mM}$ red phenol as colorimetric indicator in $100 \mathrm{ml} \mathrm{H}_{2} \mathrm{O}$. The $\mathrm{pH}$ of the reaction mixture was adjusted to 7.6. The hG-IIA or the pG-IB were solubilized in 10\% acetonitrile at a concentration of 0.02 and $0.002 \mu \mathrm{g} / \mu \mathrm{l}$; respectively. A volume of $10 \mu \mathrm{l}$ of these PLA2 solutions was incubated with $10 \mu \mathrm{l}$ of each AVLS extract for $20 \mathrm{~min}$ at room temperature. Then, $1 \mathrm{ml}$ of the PLA2 substrate was added, and the kinetic of hydrolysis was followed during $5 \mathrm{~min}$ by reading the OD at $558 \mathrm{~nm}$. The inhibition percentage was calculated by comparison with a control experiment (absence of AVLS extract) and the $\mathrm{IC}_{50}$ values were determined from the curve.

\section{Total phenols determination}

The total phenolic content (TPC) of the fractions of Aloe vera leaf skin $(A V L S)$ was estimated by a colorimetric assay, according to the method described by Singleton \& Rossi (1965) with some modifications [45]. Briefly, $1 \mathrm{ml}$ of sample at $1 \mathrm{mg} / \mathrm{ml}$ was mixed with $1 \mathrm{ml}$ of Folin-Ciocalteu reagent. After 3 min of incubation, $1 \mathrm{ml}$ of saturated $\mathrm{Na}_{2} \mathrm{CO}_{3}$ solution was added and the volume was adjusted to $10 \mathrm{ml}$ with distilled water. The reaction mixture was kept in the dark for $90 \mathrm{~min}$, after which the absorbance was read at $725 \mathrm{~nm}$. The TPC was determined using gallic acid as a standard.

\section{Antioxidant testing assays}

The antioxidant activity of $A V L S$ fractions was determined by using the following methods:

\section{DPPH radical scavenging assay}

The antioxidant activity of the AVLS fractions was measured as equivalent of hydrogen-donating or radical scavenging ability, using the DPPH method [46-48] with some modifications. Briefly, $1.5 \mathrm{ml}$ of DPPH solution at $10^{-5} \mathrm{M}$ was incubated with $1.5 \mathrm{ml}$ of $A V L S$ extracts containing variable amounts of dry weight (between 0.01 and $1 \mathrm{mg}$ ). The reaction mixture was shaken and incubated in the dark for $30 \mathrm{~min}$ at room temperature. The control experiment was performed as described above without adding any AVLS extract. The absorbance of the solution was measured at $517 \mathrm{~nm}$. The radical scavenging activity was calculated using the following equation:

$$
\text { Scavenging effect }(\%)=\left(1-\frac{\mathrm{A}_{\text {Sample }}}{\mathrm{A}_{\text {Control }}}\right) \times 100
$$

The extract concentration providing 50\% inhibition $\left(\mathrm{IC}_{50}\right)$ was calculated from the plot of the scavenging 
effect (percentage) against the extract concentration. BHT and $\alpha$-tocopherol were used as standards.

\section{Reducing power assay}

The reducing power of $A V L S$ fractions was determined according to the method of Oyaizu (1986) [49]. Solutions of variable concentration of $A V L S$ extracts were mixed with $1 \mathrm{ml}$ of $0.2 \mathrm{M}$ sodium phosphate buffer at $\mathrm{pH} 6.6$ and $1 \mathrm{ml}$ of $1 \%$ potassium ferricyanide $\left(\mathrm{K}_{3} \mathrm{Fe}\right.$ $\left.(\mathrm{CN})_{6}\right)$. The obtained reaction mixture was then incubated at $50^{\circ} \mathrm{C}$ for $20 \mathrm{~min}$. Next, $1 \mathrm{ml}$ of $10 \%(\mathrm{w} / \mathrm{v})$ trichloroacetic acid was added to the mixture which centrifuged at $3000 \mathrm{rpm}$ for $10 \mathrm{~min}$. The upper layer solution $(2.5 \mathrm{ml})$ was mixed with $2.5 \mathrm{ml}$ of deionised water and $0.5 \mathrm{ml}$ of fresh ferric chloride at $0.1 \%$. The absorbance was measured at $700 \mathrm{~nm}$. Higher absorbance of the reaction mixture indicates greater reducing power.

\section{Statistical analysis and correlation study}

Experimental results were given as mean value \pm SD of three separate experiments. Statistical analysis was conducted using Microsoft Excel software. Differences at $P<0.05$, using student's $t$-test, were considered to be significant.

Correlation study was performed using the Graphic Pad Prism software, version 5.01.

\section{Abbreviations}

TPC: total phenol content; AVLS: Aloe vera leaf skin; DPPH: 2,2-diphenyl-1picrylhydrazyl; NaTDC: sodium taurodeoxycholate; BHT: Butylhydroxytoluene GAE: Gallic acid equivalent; PLA2: Phospholipase A2.

\section{Acknowledgements}

This work is part of a PhD thesis by Maher Kammoun, whose research was supported financially by "Ministère de la recherche scientifique-Tunisia" through a grant to "Laboratoire de Biochimie et de Génie Enzymatique des Lipases-ENIS" (Tunisia)

\section{Author details}

${ }^{1}$ Laboratoire de Biochimie et de Génie Enzymatique des Lipases, Ecole Nationale d'Ingénieurs de Sfax, University of Sfax, Tunisia. ²aboratoire de Chimie des Substances Naturelles, Faculté des Sciences de Sfax, University of Sfax, Tunisia.

\section{Authors' contributions}

MK and SM carried out all the studies, analyzed the data and drafted the manuscript. YBA helped with the analysis of the data and to correct the manuscript. YG helped with the discussion of the data and the correction of the manuscript. MD helped with the discussion. SB participated in the study design and helped to draft the manuscript. All authors have read and approved the final manuscript.

\section{Competing interests}

The authors declare that they have no competing interests.

Received: 12 January 2011 Accepted: 11 February 2011

Published: 11 February 2011

\section{References}

1. Eggli U: Illustrated Handbook of Succulent plants: Monocotyledons. Springer 2001, 102-186.
2. Reynolds T: The compounds in Aloe leaf exudates: Review. Botanical Journal of the Linnean Society 1985, 90:157-177.

3. Grindly D, Reynolds T: The Aloe vera phenomenon. A Review of the properties and modern uses of the leaf parenchyma. Journal of Ethnopharmacology 1986, 16:117-151.

4. Haller JJS: A drug for all seasons: medical and pharm. History of Aloe. Bulletin of the New York Academy of Medicine 1990, 66:647-659.

5. Okamura N, Hine N, Harada S, Fujioka T, M K, Yagi A: Three chromone components from Aloe vera leaves. Phytochemistry 1996, 43:495-498.

6. Okamura N, Hine N, Tateyama Y, Nakazawa M, Fujioka T, M K, Yagi A: Three chromones of Aloe vera leaves. Phytochemistry 1997, 45:1511-1513.

7. Okamura N, Hine N, Tateyama Y, Nakazawa M, Fujioka T, K M, Yagi A: Five chromones from Aloe vera leaves. Phytochemistry 1998, 49:219-223.

8. Dagne E, Bisrat D, A V, BE WW: Chemistry of Aloe Species. Current Organic Chemistry 2000, 4:1055-1078.

9. Seongwon C, Myung-Hee C: A review on the relationship between aloe vera components and their biologic effects. Seminars in Integrative Medicine 2003, 1:53-62

10. Sultana B, Anwar F: Flavanols (Kaempeferol, quercitin, myricetin) contents of selected fruits, vegetables and medicinal plants. Food Chemistry 2008, 108:879-884

11. Ishii Y, Tanizawa H, Takino Y: Studies of Aloe. III: Mechanism of cathartic effect (2). Chemical and Pharmaceutical Bulletin 1990, 38:197-200.

12. Ishii $Y$, Tanizawa H, Takino Y: Studies of Aloe. IV: Mechanism of cathartic effect (3). Biological and Pharmaceutical Bulletin 1994, 17(4):495-497.

13. Ishii $Y$, Tanizawa H, Takino Y: Studies of Aloe. V: Mechanism of cathartic effect (3). Biological and Pharmaceutical Bulletin 1994, 17(5):651-653.

14. Akao T, Che QM, Kobashi K, Hattori M, Namba T: A purgative action of barbaloin is induced by Eubacterium sp. Strain BAR, a human intestinal anaerobe, capable of transforming barbaloin to aloe-emodin anthrone. Biological and Pharmaceutical Bulletin 1996, 19:136-138.

15. Wang HH, Chung JG, Ho CC, Wu LT, Chang SH: Aloe-emodin effects of arylamine $\mathrm{N}$-acetyl transferase activity in the bacterium Helicobacter pylori. Planta Medica 1998, 64:176-178.

16. Tian B, Hua YJ, Ma XQ, Wang GL: Relationship between antibacterial activity of Aloe and its anthraquinone compounds. Zhongguo Zhong Yao Za Zhi 2003, 11:1034-1037.

17. Pecere T, Gazzola MV, Mucignat C, Parolin C, Vecchia FD, Cavaggioni A, Basso G, Diaspro A, Salvato B, Carli M, et al: Aloe-emodin is a new type of anticancer agent with selective activity against neuroectodermal tumors. Cancer Research 2000, 60:2800-2804

18. Lee HZ, Hsu SL, Liu MC, Wu CH: Effects and mechanisms of aloe-emodin on cell death in human lung squamous cell carcinoma. European Journal of Pharmacology 2001, 431:287-295

19. Lee $\mathrm{HZ}$ : Protein kinase $\mathrm{C}$ involvement in aloe-emodin and emodin induced apoptosis in lung carcinoma cell. British Journal of Pharmacology 2001, 134:1093-1103.

20. Jasso de Rodriguez D, Hernández-Castillo D, Rodriguez-García R, AnguloSánchez JL: Antifungal activity in vitro of Aloe vera pulp and liquid fraction against plant pathogenic fungi. Industrial Crops and Products 2005, 21:81-87.

21. Lee KY, Weintraub ST, Yu BP: Isolation and identification of a phenolic antioxidant from Aloe barbadensis. Free radical biology and medicine 2000, 28:261-265.

22. $\mathrm{Hu} Y, \mathrm{Xu} J, \mathrm{Hu} \mathrm{Q}$ : Evaluation of Antioxidant Potential of Aloe vera (Aloe barbadensis Miller) Extracts. Journal of Agricultural and Food Chemistry 2003, 51(26):7788-7791.

23. $\mathrm{Hu} Q, \mathrm{Hu} Y, \mathrm{Xu}$ J: Free radical-scavenging activity of Aloe vera (Aloe barbadensis Miller) extracts by supercritical carbon dioxide extraction. Food Chemistry 2005, 91:85-90.

24. Wu FH, Liu XM, Guo SH: [Study on mechanism of yangxincao capsule in regulating lipid metabolism]. Zhongguo Zhong Xi Yi Jie He Za Zhi 2006 26(2):131-134

25. Chan-hui L, chang-hai W, Zhi-liang X, Yi W: Isolation, chemical characterization and antioxidant activities of two polysaccharides from the gel and the skin of Aloe barbadensis Miller irrigated with sea water. Process Biochemistry 2007, 42:961-970.

26. Balsinde J, Balboa MA, Insel PA, Dennis EA: Regulation and inhibition of phospholipase A2. Annu Rev Pharmacol Toxicol 1999, 39:175-189.

27. Six DA, Dennis EA: The expanding superfamily of phospholipase $A(2)$ enzymes: classification and characterization. Biochim Biophys Acta 2000, 1488(1-2):1-19. 
28. Pruzanski W, Vadas P: Phospholipase A2-a mediator between proximal and distal effectors of inflammation. Immunol Today 1991, 12(5):143-146.

29. Rola-Pleszeynski M, Thivierge M, Gagnon N, Lacasse C, Stankova J: Differential regulation of cytokine and cytokine receptor genes by PAF, LTB4 and PGE2. Journal of lipid mediators 1993, 6:175-181.

30. Tibes U, Friebe WG: Phospholipase A2 inhibitors in development. Expert opinion on investigational drugs 1997, 6:279-298.

31. Duh P: Antioxidant activity of water extract of four Harng Jyur (Chrysanthemum morifolium Ramat.) varieties in soybean oil emulsion. Food Chemistry 1999, 66:471-476.

32. Da Silva SL, Calgarotto AK, Maso V, Damico DCS, Baldasso P, Veber CL, Villar JAFP, Oliveira ARM, M C Jr, Oliveira KMT, et al: Molecular modeling and inhibition of phospholipase A2 by polyhydroxy phenolic compounds. European Journal of Medicinal Chemistry 2009, 44:312-321.

33. Kahkonen MP, Hopia Al, Vuorela HJ, Rauha JP, Pihlaja K, Kujala TS, Heinonen M: Antioxidant activity of plant extracts containing phenolic compounds. Journal of Agricultural and Food Chemistry 1999, 47:3954-3962.

34. Shahidi F, Marian N: Phenolics in food and nutraceuticals. CRS Press LLC, Boca Raton, FL 2003, 1:144-150.

35. Habeeb F, Stables G, F B, Nong S, Cameron P, Plevin R, Ferro VA: The inner gel component of Aloe vera suppresses bacterial-induced proinflammatory cytokines from human immune cells. Methods 2007, 42:388-393.

36. Dong CZ, Ahamada-Himidi A, Plocki S, Aoun D, Touaibia M, Meddad-Bel Habich N, Huet J, Redeuilh C, Ombetta JE, Godfroid JJ, et al: Inhibition of secretory phospholipase A2. 2-Synthesis and structure-activity relationship studies of 4,5-dihydro-3-(4-tetradecyloxybenzyl)-1,2,4-4Hoxadiazol-5-one (PMS1062) derivatives specific for group II enzyme. Bioorg Med Chem 2005, 13(6):1989-2007.

37. Singer AG, Ghomashchi F, Le Calvez C, Bollinger J, Bezzine S, Rouault M, Sadilek M, Nguyen E, Lazdunski M, Lambeau G, et al: Interfacial kinetic and binding properties of the complete set of human and mouse groups I, II, V, X, and XII secreted phospholipases A2. J Biol Chem 2002, 277(50):48535-48549.

38. Velioglu YS, Mazza G, Gao L, Oomah BD: Antioxidant activity and total phenolics in selected fruits, vegetables and grain products. Journal of Agricultural and Food Chemistry 1998, 46:4113-4117.

39. Yagi A, T S: Anti-inflammatory constituents, Aloesin and Aloemannan in Aloe Species and effects of Tanshinon VI in Salvia miltiorrhiza on Heart. Yakugaku zasshi 2003, 123(7):517-532.

40. Parc MY, Kwon HJ, Sung MK: Evaluation of Aloin and Aloe-Emodin as anti-inflammatory agents in Aloe by using murine macrophages. Bioscience Biotechnology and Biochemistry 2009, 73(4):828-932.

41. Esua MF, Rauwald JW: Novel bioactive maloyl glucans from Aloe vera gel: isolation, structure elucidation and in vitro bioassays. Carbohydrate Research 2006, 341:355-364.

42. Bouquet A, Paris R: Note sur le Dionchorophyllum thollonii Baill. Plantes médicinales et phytothérapie 1967, 1(4):214-220.

43. Paris R, Nothis A: Sur quelques plantes de nouvelle Calédonie. Plantes médicinales et phytothérapie 1969, 3:274-287.

44. De Araújo AL, Radvanyi F: Determination of phospholypase A2 activity by a colorimetric assay using a pH indicator. Toxicon 1987, 25(11):1181-1188.

45. Singleton VL, Ross JAJ: Colorimetry of total phenolics with phosphomolybdic-phosphotungstic acid reagents. American Journal of Enology and Viticulture 1965, 16:144-158.

46. Brand-Williams W, Cuvelier ME, Berset C: Use of free radical method to evaluate antioxidant activity. LWT-Food Science and Technology 1995, 28(1):25-30

47. Chen Y, Wang MF, Rosen RT, Ho CT: 2, 2-Diphenyl-1-picrylhydrazyl radicalscavenging active components from Polygonum multiflorum Thunb. Journal of Agricultural and Food Chemistry 1999, 47(6):2226-2228.

48. Naik GH, Priyadarsini Kl, Satav JG, Banavalicar MM, Sohoni PP, Biyani MK, Mohan H: Comparative antioxidant activity of individual herbal components used in ayurvedic medicine. Phytochemistry 2003, 63:97-104.

49. Oyaizu M: Studies on products of browning reaction prepared from glucosamine. Japanese Journal of Nutrition 1986, 44:307-315.

doi:10.1186/1476-511X-10-30

Cite this article as: Kammoun et al:: In vitro study of the PLA2 inhibition and antioxidant activities of Aloe vera leaf skin extracts. Lipids in Health and Disease 2011 10:30.

\section{Submit your next manuscript to BioMed Central and take full advantage of:}

- Convenient online submission

- Thorough peer review

- No space constraints or color figure charges

- Immediate publication on acceptance

- Inclusion in PubMed, CAS, Scopus and Google Scholar

- Research which is freely available for redistribution 